\title{
Computed Tomography utilization in minor head injury
}

\author{
Anitha Durai, Rama Prakasha Saya* \\ From International Summit on Emergency Medicine and Trauma 2014 \\ Puducherry, India. 12-16 February 2014
}

\section{Objective}

To study the utility of Computed Tomography (CT) in patients with Minor Head Injury (MHI) with respect to certain clinical findings.

\section{Methods}

This descriptive, observational study was conducted at JIPMER, Puducherry, India. All cases of Minor Head Injury (MHI) with a Glasgow Coma Scale (GCS) score of $\geq 13$ who attended the Emergency Department (ED) during the period of 9th September to 30th September were included and the results were analysed using SPSS version 16.

\section{Results}

Of the 132 cases referred for CT brain, 109 had a GCS score of less than 13 on initial evaluation. Among 109 cases with MHI, 90 were males and 64 (58.7\%) were in the age group of $14-44$ years. 78 cases were Road Traffic Accident victims, 17 were assaulted and 14 had history of fall. Twenty six (23.9\%) had abnormal CT findings. Skull fracture was the commonest finding $(19,17.4 \%)$, followed by contusion $(4,3.7 \%)$ and haemorrhage $(\mathrm{EDH} / \mathrm{SDH} / \mathrm{ICH})(3,2.8 \%)$. The logistic regression analysis showed that Loss of Consciousness (LOC) or amnesia $(p=0.045)$ and female sex $(p=0.048)$ were associated with abnormal CT findings.

\section{Limitations}

Single centre study, lack of assessment of all associated variables and limited sample size were the main limitations of the study.

\footnotetext{
* Correspondence: dr_prakashbhat@yahoo.co.in

Department of Emergency Medicine, Jawaharlal Institute of Postgraduate Medical Education and Research, Puducherry, India
}

\section{Conclusion}

A higher proportion of abnormal CT scans related to trauma after minor head injury in this study highlights the need for promotion of safety measures in such risk groups. Abnormal CT scans related to trauma after MHI can be predicted by the presence of certain risk factors for the same.

Published: 25 July 2014

doi:10.1186/1865-1380-7-S1-O4

Cite this article as: Durai and Saya: Computed Tomography utilization in minor head injury. International Journal of Emergency Medicine 2014 7(Suppl 1):04.

\section{SpringerOpen ${ }^{\odot}$}

(c) 2014 Durai and Saya; licensee Springer This is an Open Access article distributed under the terms of the Creative Commons Attribution License (http://creativecommons.org/licenses/by/2.0), which permits unrestricted use, distribution, and reproduction in any medium, provided the original work is properly credited.
Submit your manuscript to a SpringerOpen ${ }^{\circ}$ journal and benefit from:

- Convenient online submission

- Rigorous peer review

- Immediate publication on acceptance

- Open access: articles freely available online

- High visibility within the field

Retaining the copyright to your article

Submit your next manuscript at $>$ springeropen.com 